\title{
Classroom Technology Mediation among Schools in Bulacan: Basis for the In-Service Training of Teachers
}

\author{
Romulo B. Mercado Jr. ${ }^{1}$ \\ ${ }^{1}$ College of Education, Bulacan State University, City of Malolos Bulacan, Philippines, 3000
}

\begin{abstract}
Background/Objectives: The emerging trend in the modernization of global education in the 21 st century posed challenges to the teaching-learning process in the Philippines especially in the area of educational technology. It is for this concern that this study was conducted to explore the extent of competence of the teachers in utilizing various technology in teaching and discovering their influence to the learning interests of their students. Methods/Statistical analysis: The study used simple random sampling among 368 teachers and students of both public and private schools in the different Divisions of the province of Bulacan from Grade 1 to Grade 10 . The researcher employed descriptive research method using survey questionnaires, frequency distribution, mean score, percentage and standard deviation to investigate the condition in the teaching-learning relative to the technology mediation utilized by the teachers. Findings: The results showed that classrooms have available basic media technology to facilitate learning and both respondents were moderately familiar in using them to classroom teaching and learning process. Relatively, both respondents find these media technologies useful in teaching and learning activities in the classroom. Improvements/Applications: The study presents the conclusion that technology mediation among schools in Bulacan was integrated in the curriculum and both respondents were moderately familiar in using them.
\end{abstract}

\section{Index Terms}

Education technology, Teaching-learning process, Technology mediation, In-service training

\footnotetext{
Corresponding author: Romulo B. Mercado Jr.

romymercadojr_bsu@yahoo.com.ph

- Manuscript received July 10, 2017.

- Revised August 6, 2017; Accepted September 1, 2017.

- Date of publication September 30, 2017.

(c) The Academic Society of Convergence Science Inc.

2546-1583 @ 2017 IJEMR. Personal use is permitted, but republication/redistribution requires IJEMR permission.
} 


\section{INTRODUCTION}

The 21 st education requires teachers to possess communication skills, learning and innovation skills, life and career skills and information, media, and technology skills. A teacher must embody them to remain relevant, interesting, and survive in this computer era and be able to contribute to the development of 21 st century learners. One area that captured the curiosity of the researcher to conduct this study is the extent of skills of the teachers in utilizing information, media and technology in their classroom teaching.

Nowadays, the emerging trend in teaching during the 21 st century involves vast numbers of technology mediated approaches using personal computers, CDROMS, on line services, the World Wide Web and other innovative technologies in the classrooms of schools worldwide. These technological innovations in teaching have enriched the curricula and modified the types and styles of teaching available in the classroom. Discovery of newer technologies every day is increasing steadily and are now even used in traditional classrooms in the Philippines.

Basic Education in the Philippines faces a lot of challenges. The changes in the curriculum, limited IT resources and spiraling changes and improvement becomes overwhelming for administrators and teachers. Today's education also presents new pedagogies. The resurgence of the constructivist model has brought about cooperative and collaborative learning, multiple- intelligence, discovery learning, and project-based learning, to name a few. Some educators have taken a more creative approach by allowing technology to play a role in the teaching and learning process (Matulac, 2004)[1].

Teachers' role in this technological intervention in classrooms is significant in inducing the learning process. Teachers are developers of resource materials and at the same time activity builders and creators of new learning environments (Ravet and Layte as cited in Harden and Crosby, 2000)[2]. Thus, it is imperative for them to continually further their technological literacy. Teachers need to keep up with the accelerating development of technology and learn to integrate the emerging types of media into their instruction and productivity. Their lesson plans must then be adaptable and flexible. These must evolve and change as technology does to ensure that these, along with the teachers themselves, remain relevant. As Lever-Duffy and McDonald (2011) [3] mentioned in their book, teachers cannot be imagined as unable to read and write. Further, that we should no more be able to imagine a teacher unable to use technology. Educational technology skills are, for today's educators, essential skills.

Moreover, with the diversity of learners, breakthroughs in technology and multiple teacher perspectives, an innovative teaching is one of the answers to the global demands for quality education (Bilbao et.al, 2012)[4]. Macasaet (2013)[5] in his report cited the numbers of articles, studies and works of various authors to articulate the use of technology in education. Accordingly, it has significantly aided students in performing their school-related tasks. Clegg and Bailey (2008)[6] assert that with the utilization of mobile devices such as laptops and tablet computers, the learning process for the students become more fun and conducive due to the user-interactivity and appealing visuals present in these learning tools.

In the Philippines, President Benigno Aquino announced during the launch of the country's K-12 curriculum that the government eyes the use of tablet computers in public schools in lieu of traditional textbooks (Enterprise Innovation, 2012)[7]. Furthermore, there exist various programs by the government, non-government organizations and private corporations in the Philippines that aim to provide one laptop computer per child. With the presence of laptops in the classrooms, students become more engaged and involved in school-related activities (Macasaet, 2013)[5].

In addition to mobile devices, the internet also plays a very vital role in helping the students in their education. According to a study conducted by Project Tomorrow (2011)[8], having access to the internet, students would be able to research information and access online textbooks, which in turn can help the students perform better inside the classroom. Furthermore, through the use of the internet, pupils would be able to communicate and collaborate with classmates for school work. Kajrekar (2008)[9] asserts that the most significant aspect of the web for education at all levels is that it dissolves the artificial wall between the classroom and the real world. Students and teachers can establish interactive communication with anybody or any source, making learning more relevant to their lives' interests and concerns.

Additionally, with the use of the internet teachers are able to communicate with their students more easily and allow them to distribute learning materials such as assignments, exercises, and tests to their pupils, as suggested by Clegg and Bailey (2008)[6]. Likewise, through the use of the internet, instructors would have access to a vast amount of resources such as pictures for illustrations, various texts for class readings and so forth.

Consequently, the Department of Education had employed a project in which all public schools in the country be connected to the internet (Calleja, 2011)[10]. DepEd Secretary Armin Luistro maintains that it is not enough that we merely continue building classrooms and toilets, the real 
revolution in education which has long-term effects can only be done through information technology.

Students benefit from utilizing computers in their education by making school work easier; likewise, the instructors benefit from the usage of technology in teaching. Gone are the days when instructors need to write out the topics on the chalkboard, prepare a Manila paper to display a text or show flash cards for Math drills. Now, presenting topics to students is as easy as a click on the keyboard, as the text or illustration immediately unfolds onscreen in a slideshow presentation (Labro, 2008)[11]. This not only makes preparing visual aids for class more efficient and less time-consuming, but it also helps keep the flow of discussion inside the classroom more interesting and more engaging to the students.

The modern classroom now requires the use of computers, the internet and mobile devices practically in every school activity. With this idea in mind, the Department of Education has planned to modernize the Philippine classrooms in line with its $\mathrm{K}$ to 12 program. Today, education at all levels is gearing towards a computer-centric learning environment. Through the implementation of technology inside the classroom, teachers and students can yield positive results within the learning environment and true-to-life situations. Thus, a decision to embrace technology teaching to support the models of teaching that emphasize learning with understanding and more active involvement is inevitable. The issue when to use technology, what technology to use, and for what purpose cannot be isolated from theories of teaching and learning that support learning with understanding.

The Apple Classrooms of Tomorrow (2009) [12] even supports the idea that technology affects teaching and learning. The results described series of instructional stages that teachers passed as they adjust in adapting to technology in teaching. (1) Entry Stage. It is often a time when teachers slightly modify classroom activities to include technology, (2) Adaptation Stage, at this stage technology becomes thoroughly integrated into teaching patterns. Teachers are often excited about using technology to prepare and present information. Teachers become more comfortable with having students pursue individual interests, but they still design and direct the activities. These teachers need to see effective models and lessons for integrating technology to help them envision a more student-centered learning environment. Collaboration and mentoring are critical at his stage; and (3) Transformation stage, technology widely changes and expands the learning environment. Transformation-stage teachers use technology seamlessly in the classroom. Projectbased learning activities are common, and students are self-directed. Students have many opportunities to design their own learning pathways, and teachers utilize new forms of assessment. There is an emphasis on higher-order thinking. These teachers continue to innovate and expand on technology use as new tools to become available.

Similarly, Bilbao (2012)[4] expounded Goldman et.al (1999) role of technology in achieving the goal of learning for understanding. Accordingly, (1) technology provides support to solution of meaningful problems. Finding answers to complex problems brought to the classrooms is one important function of technology. Unlike authentic problems or problems that occur in the real world, some problems brought to the classrooms are simulated and created with graphics, video and animation. These can be explored over and over again through technology. (2) Technology acts as cognitive support. The use of technology provides cognitive support to learners. It assumes interactions with others who are knowledgeable who can coach, model, guide and give reminders in the accomplishment of various tasks. Multimedia databases on CD-ROMs, videodiscs or the Worldwide Web provide important information source for students who are doing research. Technology can help learners visualize processes and relationships that are invisible or difficult to understand. Lastly, (3) technology promotes collaboration as well as independent learning. The concept of network can be traced back to technology. Interconnectedness in networking through technology supports collaboration. Technology provides avenues for discussion and communication among learners.

Apparently, despite these opportunities, still many teachers and future teachers feel unprepared to teach using technology for a global application in the classroom. Bilbao et.al (2012)[4] elucidated that technology remains poorly integrated into schools, despite massive acquisition of hardware. Some observations indicate that the most frequent use of computers is for drill-and-skill practice that supplements existing curricula and instructional practices.

Many factors affect this attitude or choices as identified in some studies conducted on technology integration in the classrooms. Tinio (2002)[13] in his study on Information and Communication Technology (ICT) Utilization in the Philippine Public High School indicated an implication that on the type and extent of ICT use in a school, the teachers, administrators and other school staff need capacity building and their ICT-related skill levels were less than ideal.

Furthermore, disparity that runs parallel to the private and public schools polarity is evident. The great divide still exists between the haves and the have-nots. There are academic institutions who have access to updated and state-of-the-art technology and those who do not. 
For public institutions, the presence of internet is far from ubiquitous, even at the tertiary level. Very few state universities and colleges offer wireless internet access to their students. The number of computers of these schools can hardly accommodate the entire faculty, let alone the student body. Not to mention, system requirements of their existing computers are close to obsolete (https://theredthinkingcap.wordpress.com) [14].

Considering the issues and status of utilizing and integrating information and communication technology in the classroom, this study was conducted to better understand and present the status of technology mediation that teachers employed in teaching.

\section{A. Research Problem}

This study assessed the extent of classroom technology mediation among schools in Bulacan as basis for in-service training. The study was guided by the following research questions in understanding the existing condition in the schools. First, how may the profile of the respondents be described in terms of (1) school's division, (2) category of the school, and (3) grade level? Second, how may the information and communication technology available and used by teachers and students in the classroom during the teaching and learning process be accounted as to; (1) media hardware, (2) Internet Access, and (3) Software/media applications? Third, what is the level of familiarity of the teachers and students on information and communication technology they used in schools? Fourth, how do the teachers and the students perceived the usefulness of the information and communication technology in the teaching and learning process? Lastly, what recommendation may be made to serve as basis for the continuous upgrading of skills of the teachers on ICT.

\section{Methodology}

\section{A. Sample}

The respondents of the study were composed of 184 teachers and 184 students from the four divisions of Bulacan province, namely City Schools Divisions of Malolos, Meycauayan, San Jose Del Monte and the Division of Bulacan. Teachers and students from grade 1 to grade 10 of both public and private schools of the School Year 2015-2016 were selected using simple random sampling for the study.

Sampling is a process used in statistical analysis in which a predetermined number of observations are taken from a larger population. The methodology used to sample from a larger population depends on the type of analysis being performed, but may include simple random sampling or systematic sampling. In simple random sampling each individual is chosen entirely by chance and each member of the population has an equal chance of being included in the sample. Every possible sample of a given size has the same chance of selection (http://www.investopedia.com/terms/s/sampling.as p) [15].

\section{B. Instrumentation and Data Collection}

The data were gathered using survey questionnaire consisting of two parts. The part I was composed of survey questionnaire that solicit for the respondents profile and their knowledge on the available information and communication technology (ICT) in the classroom. The part II presents survey questionnaires that draw data on the extent of the respondents' familiarity on ICT and their perception on their usefulness in the teaching-learning process. The extent of familiarity of the respondents were gathered using the survey questionnaire that contains five (5) point Likert scale with the following numeric and descriptive interpretation; 1- Not at all familiar, 2- Slightly familiar, 3- Somewhat familiar, 4Moderately familiar, and 5- Extremely familiar. Meanwhile, the perception of the respondents on the level of usefulness of the ICT to teaching-learning process were gathered using the three (3) pointLikert scale with the following numeric and descriptive interpretation; 1- Not Useful, 2- Useful, and 3-Extremely useful.

Likert developed the principle of measuring attitudes by asking people to respond to a series of statements about a topic, in terms of the extent to which they agree with them, and so tapping into the cognitive and affective components of attitudes.

The frequency scales popularized by Likert use fixed choice response formats and are designed to measure attitudes or opinions (Bowling, 2009)[16]. These ordinal scales measure levels of agreement/disagreement. It assumes that the strength/intensity of experience is linear, like on a continuum from strongly agree to strongly disagree, and makes the assumption that attitudes can be measured. Respondents may be offered a choice of five to seven or even nine pre-coded responses with the neutral point being neither agree nor disagree.

In its final form, the Likert Scale is a five (or seven) point scale which is used to allow the individual to express how much they agree or disagree with a particular statement. Each criterion used in the development of the questionnaire is defined by certain indicators which the respondents mark using the five-point Likert scale. 


\section{Data Analysis}

Descriptive statistics like frequency distribution, weighted mean, percentage, and standard deviation were used to assess the extent of familiarity of the respondents and their perception on the usefulness of the information and communication technology in the teaching-learning process in the classroom. Coolidge (2006)[17] describes the frequency distribution as one of the most important graphic presentations in modern statistics because it gives an immediate graphic or tabled picture of data and it can as well handle small or large samples. In addition, he defines mean as the arithmetic average of a set of scores. It is obtained by taking the sum of all the numbers in the set and dividing by the total number of scores in the set.

\section{RESUltS AND DisCUSSION}

The survey conducted to the teachers and students of Bulacan province consisting of four (4) Department of Education Divisions from private and public schools to assess the extent of technology mediation in the classroom as presented in Table 1 showed that there are available media technology in the classroom classified particularly on media hardware and software or media applications. The media hardware available were LCD projector, overhead projector, laptop or computer, lapel audio system, smart phones, DVD player, and LCD/LED TV while software and media applications available in the classrooms were MS Word, MS Excel, MS Power Point, Adobe Photoshop, Paint, Moviemaker, and VLC Media player. Moreover, both respondents agreed that based on their assessment, laptop or computer is the most common and available teaching technology hardware in the classroom with the percentile rating of $82.61 \%$ of teachers and $55.98 \%$ for students. On the other hand, both respondents agreed that MS Word and MS Power Point are the two commonly available and used software or media applications in the classrooms.

The level of familiarity of the teachers and students based on the results of the survey as presented in Table 2 appeared that teacherrespondents and student-respondents have the same perception on their familiarity to media hardware available in the classrooms. The descriptive ratings translate that both respondents are moderately familiar with the following media hardware generally. These are computer, LCD projector, OHP, LCD/LED TV, lapel audio system, smart phones, DVD player. This is observable in the results of their mean scores of 4.24 and 3.82 respectively. Moreover, to test the reliability of the results of their mean scores, the standard deviation was used to determine the variance of scores. The result showed that there is no significant finding on the variance of scores of the two respondents. There is a very small standard deviation from the mean score. Hence, the result based on the computed mean score is very reliable.

Relatively on the software or media applications, the computed mean score of the teacher-respondents appeared 2.95 and the student-respondents were 3.05 . This means that they perceived that they were slightly familiar with software or media applications like MS Word, MS Excel, MS Power Point, Adobe Photoshop, Paint, Moviemaker, VLC media player. There is also very little indication of variance in the scores given by both respondents which could not even be a basis for the disparity of scores based on the computed standard deviation of 0.07 . Generally, the perception of the teacher-respondents and student-respondents on their level of familiarity to media technology was moderately familiar with an average mean score of 3.51 .

Table 1. Results on Available Media TeChnOlogy in the Classroom

\begin{tabular}{|c|c|c|c|c|c|}
\hline \multicolumn{2}{|c|}{ Media Technology } & $\begin{array}{c}184 \\
\text { Teachers }\end{array}$ & $\%$ & $\begin{array}{c}184 \\
\text { Students }\end{array}$ & $\%$ \\
\hline \multicolumn{6}{|c|}{ Media Hardware } \\
\hline 1 & Computer/Laptop & 152 & 82.61 & 103 & 55.98 \\
\hline 2 & LCD Projector & 118 & 64.13 & 8 & 4.35 \\
\hline 3 & Over-Head Projector & 2 & 1.09 & 11 & 5.98 \\
\hline 4 & LCD/LED TV & 28 & 15.22 & 25 & 13.59 \\
\hline 5 & Lapel & 20 & 10.87 & 15 & 8.15 \\
\hline 6 & Smart phones/Android Phones & 40 & 21.74 & 82 & 44.57 \\
\hline 7 & DVD player & 7 & 3.80 & 10 & 5.43 \\
\hline \multicolumn{6}{|c|}{ Software/Media Applications } \\
\hline 1 & MS Word & 150 & 81.52 & 97 & 52.72 \\
\hline 2 & MS Excel & 27 & 14.67 & 20 & 10.87 \\
\hline 3 & MS Power Point & 142 & 77.17 & 136 & 73.91 \\
\hline 4 & Adobe Photoshop & 2 & 1.09 & 18 & 9.78 \\
\hline 5 & Paint & 8 & 4.35 & 2 & 1.09 \\
\hline 6 & Moviemaker & 8 & 4.35 & 5 & 2.72 \\
\hline 7 & VLC Media Player & 9 & 4.89 & 2 & 1.09 \\
\hline
\end{tabular}


Table 2. Results ON THE LEVEl OF FAMILIARITY OF THE TEACHERS AND STUDENTS ON MEDIA TECHNOLOGY

\begin{tabular}{l|l|l|l|l}
\hline \hline Media Technology & Teacher's (X) & $\begin{array}{l}\text { Descriptive } \\
\text { Rating }\end{array}$ & $\begin{array}{l}\text { Student's } \\
\text { (X) }\end{array}$ & Descriptive Rating \\
\hline $\begin{array}{l}\text { Media Hardware i.e. computer, lcd } \\
\text { projector, OHP, LCD/LED tv, lapel audio } \\
\text { system, smartphones, dvd player }\end{array}$ & 4.24 & $\begin{array}{l}\text { Moderately } \\
\text { Familiar }\end{array}$ & 3.82 & Moderately Familiar 0.29 \\
\hline $\begin{array}{l}\text { Software or Media Application like MS } \\
\text { word, excel, powerpoint, adobe } \\
\text { photoshop, paint, moviemaker, vlc media } \\
\text { player }\end{array}$ & 2.95 & $\begin{array}{l}\text { Somewhat } \\
\text { Familiar }\end{array}$ & 3.05 & Somewhat Familiar \\
\hline
\end{tabular}

Hence, the perception of both respondents appeared congruent with each other.

Finally, the perception of the teacher-respondents and student respondents on the usefulness of the information and communication technology in the teaching and learning process appeared in Table 3. The perception of the respondents on the usefulness of the media technology like media hardware, internet access, and software and media applications were gathered using fourteen item questionnaires focusing on the three major roles of technology in achieving goal for learning for understanding which were clustered according to its purpose like solutions to meaningful problems, acts as cognitive support, and promotion of collaborative and independent learning (Bilbao. Purita P. et.al, 2012)[4].

The results appeared that the teacher-respondents perceived media technology as useful based on the computed mean scores of 2.47 while the studentrespondents had a perception different from the other group of respondents. They perceived that media technologies were extremely useful in learning based on the computed mean score of 2.50. Further test to determine the variance in their perception was conducted by using standard deviation, the result supported a non-variance on scores appeared based on the computed standard deviation of 0.02 . Additionally, the average mean scores of 2.48 of the two respondents based on their perception appeared that media technology was useful in their teaching and learning activities which was evident from the computed mean score.

From all the findings drawn from the gathered data, it may be concluded that there are available media technology in all schools surveyed in the four divisions of the province of Bulacan. However, these technologies are limited to few and popular media hardware and software applications common in teaching and learning activities in the classroom. These technologies were laptop or computers, LCD projector, MS Words and MS Power Point. Teachers and students agreed that they were moderately familiar on available media technology in the classroom and they also both agreed that these were useful in the teaching and learning process in the school.

\section{RECOMMENDATIONS}

In the light of the foregoing findings and conclusions the following recommendations are made. (1) Training on information and communication technology literacy and ICT integration in the curriculum may be conducted to the teachers of schools divisions used for the study for them to be become widely and extremely familiar with all the available technologies around them. (2) Budget for the acquisition of ICT equipment and software must be increased especially for public schools to fully support the needs of the school's classroom and teachers. (3) Active and continuous monitoring scheme must be continuously and consistently implemented by the Department of Education to better follow-up and understand the status of ICT program among schools in the

Table 3. Results on the Perception of the Teachers and Students on the Usefulness of Media TeChnOlogy in the Teaching AND LEARNING

\begin{tabular}{l|l|l|l|l|l|l}
\hline \hline $\begin{array}{l}\text { Teachers' Mean } \\
\text { Score }\end{array}$ & Descriptive Rating & $\begin{array}{l}\text { Students' Mean } \\
\text { Score }\end{array}$ & Descriptive Rating & SD & $\begin{array}{l}\text { Average Mean } \\
\text { Score }\end{array}$ & $\begin{array}{l}\text { Descriptive } \\
\text { Rating }\end{array}$ \\
\hline 2.47 & Useful & 2.50 & Extremely Useful & 0.02 & 2.48 & Useful \\
\hline \hline
\end{tabular}


divisions. (4) And lastly, for the teachers to open themselves to opportunities of adopting technologies to their teaching practice without worries and anxiety or even resistance to learn new things. Teachers are lifelong learners and teaching is the essence of their being.

\section{REFERENCES}

[1] Matulac, Melvin R. (2004). Experiences in Technology Integration. (2016, August 3). Retrieved from http://www.fit-ed.org/ictcongress/paper/matulac.html.

[2] Crosby, J. and Harden, R.M. (2000). The good teacher is more than a lecturer - the twelve roles of the teacher. Medical Teacher, 22 (4), 334-347.

[3] Lever-Duffy, J. and McDonald, J. (2011). Teaching and learning with technology. Boston: Pearson.

[4] Bilbao, P. P., Corpuz, B. B., Llagas, A. T., \& Salandanan, G.G. (2012). The Teaching Profession. Quezon City, Metro. Manila: Lorimar Publishing House.

[5] Macasaet, JohnRufino I. (2013). Uplifting Education Through Technology. (2016, July 28). Retrieved from http://www.academia.edu/4954448/Uplifting_Education_in the_Through_Technolo gy_Report.

[6] Computer-Based Learning. (2008). In S. R. Clegg and J. R. Bailey (Eds.), International Encyclopedia of Organizational Studies (Vol. 1, pp. 238-242). Thousand Oaks, CA: SAGE Publications. (2016, July 6). Retrieved from http://go.galegroup.com/ps/i.do?id=GALE\%7CCX26614000 $92 \& v=2.1 \& u=$ hdiliman $\& \mathrm{it}=\mathrm{r} \& \mathrm{p}=\mathrm{GVRL} \& \mathrm{sw}=$.

[7] Enterprise Innovation. (2012). Philippines eyes use of tablets for new K-12 basic education program. (2016, July 29). Retrieved from http://enterpriseinnovation.net/article /philippines-eyes-use-tablets-new-k-12-basic-educationprogram.

[8] Project, T. (2011). The New 3 E's of Education: Enabled, Engaged, Empowered--How Today's Students Are Leveraging Emerging Technologies for Learning. Speak Up 2010 National Findings: K-12 Students \& Parents. Project Tomorrow. Retrieved from http://www.eric.ed.gov/PDFS /ED536066.pdf.

[9] Kajrekar, F. (2012). Effectiveness of Computers: Role of Computer in Education System. Indian Streams Research Journal, 2(8), 1-4.

[10] Calleja, N. (2011). All public high schools to have Internet in 2012. The Philippine Daily Inquirer. (2016, July 29). Retrieved from http://newsinfo.inquirer.net/98247/all-publichigh-schools-to-have-internet-in-2012.

[11] Labro, V. (2008). Computers help teachers, students. The Philippine Daily Inquirer.(2013, July 28). Retrieved from http://www.inquirer.net/specialreports/education/view.php? $\mathrm{db}=1 \&$ article $=20081019-167225$.

[12] Apple Classroom of Tomorrow (ACTO), "How Technology Affects Teaching and Learning?”, 2009. (2016, July 5) Retrieved from http://www.teachervision:fer.com/teachingmethods/resource/5810.html.

[13] Tinio, Victoria. L. (2002). Survey of Information and Communication Technology Utilization in Philippine Public High School, Commissioned by the Center of International Cooperation for Computerization Government of Japan. (2016, May 2) Retrieved from http://www.apdip.net/ publications/iespprimers/emprimer-edu.pdf.

[14] The Red Thinking Cap (2012). On the Roles of Teachers in Edtech. (2016, July 3) Retrieved from https://theredthinkingcap.wordpress.com/2012/07/22/on-theroles-of-teachers-in-edtech/.

[15] Investopedia .com (2016). Sampling. (2016, July 3) Retrieved from http://www.investopedia.com/terms/s/sampling.asp
[16] Bowling, A. (2009). Research methods in health. Investigating health and health services (3rd edition). London: McGraw-Hill, Open University Press.

[17] Coolidge, F.L. (2006). Statistics: a gentle introduction. (2nd ed.) California: SAGE Publication, Inc. 